\title{
Function of English Sub-tests of the INUEE for Male Candidates
}

\author{
Maryam Javadizad \\ Department of English, Najafabad Branch, Islamic Azad University, Najafabad, Iran \\ Email: maryam_javadizad@yahoo.com \\ Hossein Barati \\ English Department, University of Isfahan, Isfahan, Iran \\ Email: h.barati@gmail.com \\ Akbar Hesabi \\ English Department, University of Isfahan, Isfahan, Iran \\ Email: a.hesabi11@yahoo.com
}

\begin{abstract}
Iranian National University Entrance Exam (INUEE) plays a vital role in the life of Iranian students in terms of screening applicants for higher education. The present study aimed to investigate if there is any highly positive correlation between various English sub-tests of the INUEE for male candidates. The study utilized Pearson Product Moment Correlation Coefficient formula to investigate correlation coefficient for a sample of 329 students randomly selected out of a population of 90858 male candidates who sat for the INUEE. The results of the study identified a high correlation between grammar and reading comprehension, vocabulary and reading comprehension, vocabulary and grammar, and language functions and reading comprehension sub-tests for male students.
\end{abstract}

Index Terms - correction for attenuation, correlation coefficient, Iranian National University Entrance Exam (INUEE), high-stakes test

\section{INTRODUCTION}

Testing in general and language testing in particular is a challenging field. In other words, tests are used to make decisions which influence people's lives. Therefore, they must provide as accurate information as possible to enable test-makers to make fair decisions. This is something which makes testing a very complicated task (Safikhani, 2009). The INUEE in Iran which is specific for language courses is a public test which is administered annually and has a great number of stake holders. As Pearson (1988) notes, public examinations influence the attitudes, behavior, and motivation of teachers and learners. In this respect various studies indicate a range of rather negative feelings which stems from the test. Spratt (2005) claims that students show mixed feelings toward a high-stakes test. Such a test made them work hard but it was not an accurate indicator of their study and so did not relate specifically to their future needs. One of the variables that affect on test results is the relationship between various sub-tests in a test.

According to Adams (1980, cited in Lin, 2002), "syntactic competence is an important dimension of linguistic competence in general". Similarly, Berman (1948, cited in Lin, 2002) notes that "efficient foreign language readers must rely in part on syntactic devices to get at text meaning". In proposing a focus on grammatical patterns, Hunston (1997) emphasize that the connection of word and pattern is not random and the groups of words in patterns tend to share aspects of meaning.

Rivers (1983) conveyed that for successful second language use the acquisition of adequate vocabulary is necessary because without an extensive vocabulary the language learner will not be able to use the structures and functions of the second language he/she may have learned for comprehensible communication. Laufer \& Hulstijn (2001) also pointed out that many second language learners are hampered in reading comprehension and other language skills just because of a simple lack of word knowledge.

Such studies are especially important in high-stakes test contexts. This was the motive for the present study which intends to check the relationship between different sub-tests in a high-stakes test (Iranian National University Entrance Exam) administered annually in Iran.

\section{LITERATURE REVIEW}

Alderson (1993) proved a strong connection between grammar and reading comprehension. In Alderson's study, the researcher tried to investigate whether there is any correlation between different parts of IELTS test. During the study, he found a very high correlation between the grammar test and different tests of reading comprehension. For example, 
the correlation between the grammar test and the Science and Technology Reading test was $.80(\mathrm{r}=.80)$. However, studies in this area are problematic. Alderson (1993) observed that "the results, then, appear to show that a (vaguely defined) generalized grammatical ability is an important component in reading in a foreign language" (p. 218). But, as he himself admits, he was unable to avoid a degree of "contamination" of the grammar variable, since his grammar measure involved the processing of sentence semantics, e.g. the referential and sense meanings of lexical items. Since reading involves the extraction and reconstruction of meaning (including the processing of appropriate forms in meaningful contexts), it is clear that any grammar test with a heavy emphasis on meaning is likely to overlap with reading tests.

Also, a number of empirical studies investigated the roles of different aspects of $\mathrm{L}_{2}$ vocabulary knowledge in reading comprehension. Koda's (1989) study of 24 college students who were learning Japanese as a foreign language found equally strong correlations between a self-made vocabulary test and two reading tests, one being a cloze test and the other paragraph comprehension. Koda (1989) reported a correlation of $.69(r=.69)$ between the learners' scores on the vocabulary test and the cloze test and a correlation of $.74(\mathrm{r}=.74)$ between their scores on the vocabulary test and the paragraph comprehension test.

Iranian National University Entrance Exam (INUEE) in Iran, as a high-stakes selection test, might be influential on the high school and pre-university teachers and students. In this regard, the present study seeks to explore the appropriateness of the specialized English section of the INUEE in measuring different abilities of male students in EFL.

Based on what has been discussed the following question was raised:

- Is there any relationship in the performance of Iranian male test takers on the various sub-tests of the specialized English section of the INUEE?

According to the question mentioned above the study attempted to address the following null research hypothesis:

- There is no correlation coefficient between different sub-tests of the specialized English section of the INUEE for male candidates.

\section{METHOD}

\section{A. Subjects}

The participants of this study were selected randomly from a population of about 276,164 high school graduates of Natural Sciences, Humanities, and Mathematics who sat for the specialized English section of the INUEE (90,858 male and 185,306 female). At first the population was divided based on their gender. The final participants were selected randomly from male group. A total sample of 329 test-takers was selected randomly for the present investigation. The assumption was that a large sample may help finding out statistically significant results where the effect is seemingly small and meaningless.

\section{B. Materials}

\section{"Iranian National University Entrance Exam" (INUEE)}

The Iranian National University Entrance Exam evaluates students' general language ability to select them for studying at higher education (Appendix I). This test has five similar forms. High school graduates sit for one of the three main forms which are related to Natural Sciences, Humanities, or Mathematics. The other two forms of the test are related to Arts and English. The test-takers if interested can take two forms of the test, one related to English or art and the other related to Natural Sciences, Humanities, or Mathematics. The test which is prepared to select students for the English major has two parts. The second part which is specially designed to screen candidates for studying English as a foreign language (EFL) consists of 70 multiple-choice items in six areas of grammar (12 items), vocabulary (20 items), language structure (word order) (4 items), language functions (4 items), cloze test (15 items), and reading comprehension (15 items).

\section{Data Analysis}

The data for this study are the collected results from Sanjesh Organization of the INUEE administered in 2004. The answer sheets of all the applicants for the English major (more than 90,000 male applicants) were considered in this study and 329 answer sheets were selected randomly from various groups.

To do the investigation, the scores of the participants for each sub-test were needed. Thus participants received +1 for each correct response, $-1 / 3$ for each wrong answer, and 0 for the questions which left unanswered. This is the procedure implemented by Sanjesh Organization. This procedure was done separately for each sub-test for male candidates.

The correlations between different sub-tests for male group were calculated. It includes six sub-tests. So the researcher had 15 correlations for males. To do this, the SPSS software was used.

According to Henning (1987) "when we compute a correlation matrix from a battery of sub-tests, we should bear in mind that the magnitudes of these correlation coefficients is affected by the reliabilities of the sub-tests." (p.85). To solve this problem the correction for attenuation formula was used; so the reliability of each sub-test was calculated separately by the use of Cronbach's alpha. The reliability estimates for each of the six parts of the test as well as the whole test are presented in Table 1. 
TABLE 1:

RELIABILITY ESTIMATED FOR THE SPECIALIZED ENGLISH TEST (TOTAL TEST AND SUB-TESTS)

\begin{tabular}{|l|l|l|l|l|l|l|l|}
\hline & Grammar & Vocabulary & $\begin{array}{l}\text { Language structure } \\
\text { (word order) }\end{array}$ & $\begin{array}{l}\text { Language } \\
\text { functions }\end{array}$ & $\begin{array}{l}\text { Cloze } \\
\text { Test }\end{array}$ & $\begin{array}{l}\text { Reading } \\
\text { Comprehension }\end{array}$ & $\begin{array}{l}\text { Total } \\
\text { Test }\end{array}$ \\
\hline Reliability & .55 & .59 & .54 & .53 & .61 & .64 & .89 \\
\hline
\end{tabular}

\section{RESUltS}

As discussed earlier the research question concerns the existence of correlation coefficient between different subtests of the specialized English section of the INUEE. In order to address the research question Pearson Product Moment correlation was applied on the data. This would help find out whether there is any relationship in the performance of Iranian male test-takers on the various sub-tests or not.

\section{A. Correlation between Grammar and Vocabulary Sub-tests}

This section depicts the results of correlational analysis between grammar and vocabulary sub-tests. At first, test given to the participants was scored. Pearson Product Moment correlation coefficient analysis was carried out on the results after scoring the test. The result of the analysis is presented in Figure 1 and in Table 2.

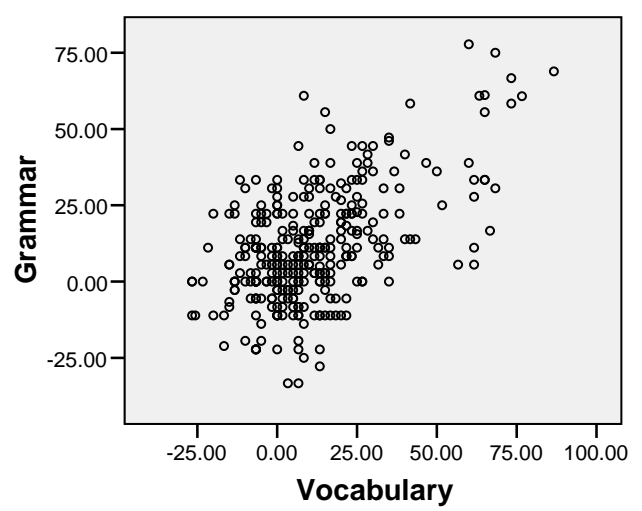

Figure 1: Scatter Diagram for the Grammar and Vocabulary Sub-tests

TABLE 2:

PEARson Product MOMENT CORRELATION COEFFICIENT BETWEEN GRAMMAR AND VocABUlaRy SUB-TESTS

\begin{tabular}{|ll|r|r|}
\hline \multicolumn{3}{|c|}{ Correlations } \\
\hline & & Grammar & Vocabulary \\
\hline Grammar & Pearson Correlation & 1 & $.500^{\star *}$ \\
& Sig. (2-tailed) & & .000 \\
& $\mathrm{~N}$ & 329 & 329 \\
\hline Vocabulary & Pearson Correlation & $.500^{* \star}$ & 1 \\
& Sig. (2-tailed) & .000 & \\
& $\mathrm{~N}$ & 329 & 329 \\
\hline
\end{tabular}

${ }^{* *}$. Correlation is significant at the 0.01 level (2-tailed).

As shown in table 2 the correlation coefficient between the scores of the grammar and vocabulary sub-tests is .50; however, after using the correction for attenuation formula it changed to .89. According to Yamini \& Rahimi (2007) the correlation coefficient is used to determine the degree of relationship between two variables. If the variables are related, there is some common variance between them. To calculate the common variance, the correlation coefficient is squared. So the common variance of two sub-tests is $79 \%$.

\section{B. Correlation between Grammar and Reading Comprehension Sub-tests}

As for the correlation between grammar and vocabulary sub-tests of the INUEE, Pearson Product Moment correlational analysis was carried out on the results of grammar and reading comprehension sub-tests after scoring the test. Table 3 and Figure 2 present the results. 


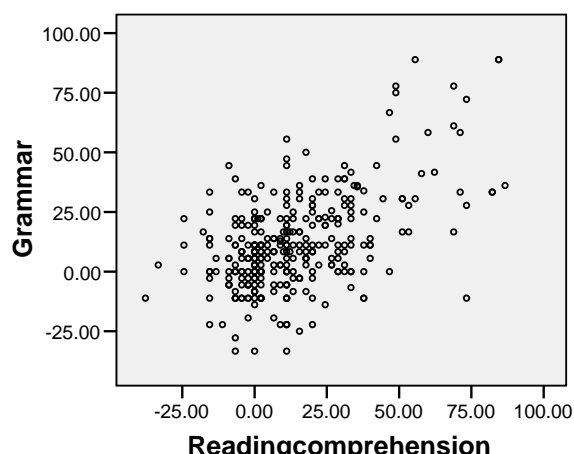

Figure 2: Scatter Diagram for the Grammar and Reading Comprehension Sub-tests

TABLE 3:

PEARSOn PRoduct Moment CORRELATION COEFFICIENT BETWEEN GRAMMAR AND READING COMPREHENSION SUB-TESTS

Correlations

\begin{tabular}{|ll|r|r|}
\hline & Grammar & $\begin{array}{c}\text { Readingcom } \\
\text { prehension }\end{array}$ \\
\hline Grammar & Pearson Correlation & 1 & $.536^{\star *}$ \\
& Sig. (2-tailed) & & .000 \\
& $\mathrm{~N}$ & 329 & 329 \\
\hline Readingcomprehension & Pearson Correlation & $.536^{\star \star}$ & 1 \\
& Sig. (2-tailed) & .000 & \\
& $\mathrm{~N}$ & 329 & 329 \\
\hline
\end{tabular}

${ }^{* *}$. Correlation is significant at the 0.01 level (2-tailed).

As demonstrated above, the correlation coefficient between the scores of the grammar and reading comprehension sub-tests is .53 which changed to .89 after using the correction for attenuation formula. The common variance for the two was, therefore .79 which indicates $79 \%$ of the variance caused by the two tests is due to their same function.

C. Correlation between Vocabulary and Reading Comprehension Sub-tests

To find out the correlation coefficient between vocabulary and reading comprehension sub-tests of the INUEE, Pearson Product Moment correlation was employed on the data. The result of the analysis is presented in Table 4 and Figure 3.

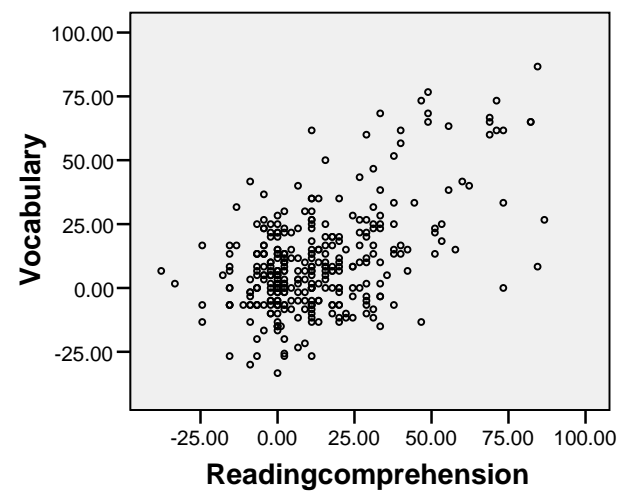

Figure 3: Scatter Diagram for the Vocabulary and Reading Comprehension Sub-tests

TABLE 4:

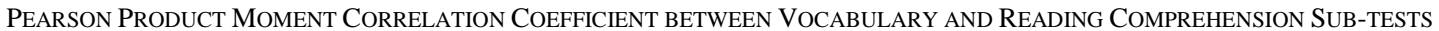

Correlations

\begin{tabular}{|ll|r|r|}
\hline & Vocabulary & $\begin{array}{c}\text { Readingcom } \\
\text { prehension }\end{array}$ \\
\hline Vocabulary & Pearson Correlation & 1 & $.536^{* \star}$ \\
& Sig. (2-tailed) & & .000 \\
& $\mathrm{~N}$ & 329 & 329 \\
\hline Readingcomprehension & Pearson Correlation & $.536^{\star \star}$ & 1 \\
& Sig. (2-tailed) & .000 & 329 \\
& $\mathrm{~N}$ & 329 & \\
\hline
\end{tabular}

${ }^{\star *}$. Correlation is significant at the 0.01 level (2-tailed). 
As demonstrated in table 4 the correlation coefficient between the scores of the vocabulary and reading comprehension sub-tests is .53 , but after using the correction for attenuation formula it changed to .86. So accordingly the common variance of two sub-tests is $73 \%$.

\section{Correlation between Language Functions and Reading Comprehension Sub-tests}

This section depicts the results of correlational analysis between the language functions and reading comprehension sub-tests of the INUEE. Pearson Product Moment correlation coefficient analysis was carried out on the data. Figure 4 and Table 5 present the results.

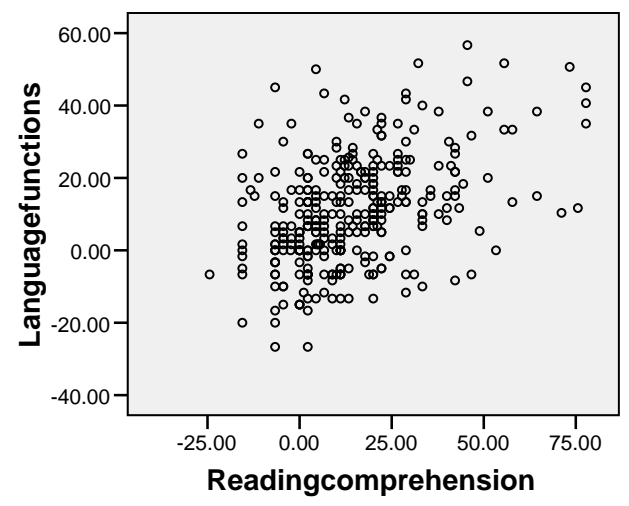

Figure 4: Scatter Diagram for the Language Functions and Reading Comprehension Sub-tests

TABLE 5:

PEARSon Product Moment CORRELATION COEFFICIENT BETWEEN LANGUAGE FunCtions AND READING COMPREHENSION Sub-TESTS

\begin{tabular}{|ll|r|r|}
\hline \multicolumn{1}{|c|}{ Correlations } \\
\hline & $\begin{array}{l}\text { Languagef } \\
\text { unctions }\end{array}$ & $\begin{array}{c}\text { Readingcom } \\
\text { prehension }\end{array}$ \\
\hline Languagefunctions & Pearson Correlation & 1 & $.520^{* *}$ \\
& Sig. (2-tailed) & 329 & .000 \\
& $\mathrm{~N}$ & $.520^{* *}$ & 329 \\
\hline Readingcomprehension & Pearson Correlation & .000 & 1 \\
& Sig. (2-tailed) & 329 & 329 \\
\hline & $\mathrm{N}$ &
\end{tabular}

As demonstrated in Table 5, the correlation coefficient between the scores of the language functions and reading comprehension sub-tests is .52 which changed to .89 after using the correction for attenuation formula. According to these results the common variance of two sub-tests is $79 \%$.

\section{E. Correlation Coefficient between Other Sub-tests}

The results of Pearson Product Moment correlation coefficient between other sub-tests of the INUEE for male candidates are mentioned in Table 6. Indeed, the correlation coefficients between these sub-tests are insufficient and are not important. The tables of correlation coefficient for these sub-tests are presented in Appendix II.

TABLE 6:

RESUlTS OF CORRELATION COEFFICIENT BETWEEN OTHER SUB-TESTS OF THE SPECIALIZED ENGLISH SECTION OF THE INUEE

\begin{tabular}{|l|l|l|l|l|l|}
\hline & $\begin{array}{l}\text { Before using the } \\
\text { correction for } \\
\text { attenuation } \\
\text { formula }\end{array}$ & $\begin{array}{l}\text { After using the } \\
\text { correction } \\
\text { attenuation } \\
\text { formula }\end{array}$ & .53 & $\begin{array}{l}\text { Before using the } \\
\text { forrection } \\
\text { for } \\
\text { attenuation } \\
\text { formula }\end{array}$ & $\begin{array}{l}\text { After using the } \\
\text { correction } \\
\text { attenuation } \\
\text { formula }\end{array}$ \\
\hline $\begin{array}{l}\text { Grammar } \\
\text { Language Structure }\end{array}$ & .29 & .57 & $\begin{array}{l}\text { Vocabulary \& } \\
\text { Language Structure }\end{array}$ & .28 \\
\hline $\begin{array}{l}\text { Grammar \& Cloze } \\
\text { Test }\end{array}$ & .33 & .56 & $\begin{array}{l}\text { Vocabulary \& Cloze } \\
\text { Test }\end{array}$ & .35 & .46 \\
\hline $\begin{array}{l}\text { Vocabulary \& } \\
\text { Language Functions }\end{array}$ & .31 & .50 & $\begin{array}{l}\text { Language Structure } \\
\& \text { Cloze Test }\end{array}$ & .24 & .59 \\
\hline $\begin{array}{l}\text { Language Structure } \\
\& \\
\text { Functions Language }\end{array}$ & .27 & .44 & $\begin{array}{l}\text { Language Functions } \\
\text { Cloze Test }\end{array}$ & .36 \\
\hline $\begin{array}{l}\text { Language Structure } \\
\& \text { Reading } \\
\text { Comprehension }\end{array}$ & .26 & .66 & & & .42 \\
\hline $\begin{array}{l}\text { Cloze Test \& } \\
\text { Reading } \\
\text { Comprehension }\end{array}$ & .41 & & & .65 \\
\hline
\end{tabular}


In this study one null research hypothesis is addressed. It claimed that there is no correlation coefficient between different sub-tests of the specialized English section of the INUEE for male candidates. According to the results there is a high correlation between grammar and vocabulary, grammar and reading comprehension, vocabulary and reading comprehension, and language functions and reading comprehension sub-tests. It shows that we can use just reading comprehension sub-test to measure candidates' knowledge in grammar, vocabulary, language functions, and reading comprehension. So, the research hypothesis in this study is rejected.

\section{DISCUSSION AND CONCLUSION}

The previous sections presented and discussed the results of correlation coefficient analyses for the English sub-tests of the INUEE administered in 1383. In this part the findings are interpreted in light of the research questions.

The research hypothesis of this study is that "there is no correlation coefficient between different sub-tests of the specialized English section of the INUEE for males". On the basis of the statistical analyses of the data obtained from the INUEE given to the participants, there is a high correlation between grammar and vocabulary $(\mathrm{r}=.89)$, grammar and reading comprehension $(\mathrm{r}=.89)$, language functions and reading comprehension $(\mathrm{r}=.89)$, and vocabulary and reading comprehension $(\mathrm{r}=.86)$; so this null hypothesis is rejected. This finding is in line with previous researches such as the study by Irvin (2001) who believed that vocabulary knowledge is an important part of reading comprehension. Besides, the National Reading Panel (Panel, 2000) stated that reading comprehension is a cognitive process that integrates complex skills and cannot been understood without examining the critical role of vocabulary learning in its development. In addition, Gestern \& Geva (2003) believed that students' vocabulary knowledge, i.e. the words they know, and students' reading comprehension of what they read are strongly correlated.

Many researchers (e.g., Alderson, 1984; Eskey, 1973) also attributed the incapacity for communicative competence in English to a poverty of vocabulary. This idea was expressed best by Savington (1997) who considered the insufficiency of vocabulary as an important factor and argues that: "this is a factual problem in speech, reading and writing. Grammar skill does not work effectively unless you have the vocabulary to express yourself" (P.78).

Moreover, Gestern \& Baker (1999) presented a research synthesis of studies conducted between 1979 and 1999 involving learning disable students and concluded that successful reading comprehension is correlated with oral reading fluency and vocabulary knowledge. In addition, based on a study of $8^{\text {th }}$ grade students, who were assessed using word recognition checklist and multiple choice vocabulary tasks, Anderson \& Freebody (1981) maintained, "a readers' general vocabulary knowledge is the single best predictor of how well that reader can understand a text" (P.3). The authors reported a high correlation between tests of vocabulary and reading comprehension tests.

In other studies like Berman (1984), and later in Urquhart \& Weir (1998), the researchers note: "Grammar is a component of reading that has been almost ignored in the research. It seems to us that this is an interesting and potentially valuable research area which L2 teachers and applied linguists are in a good position to investigate." (p.269).

As indicated all these researches have shown the crucial role of vocabulary knowledge and grammatical knowledge in reading comprehension which is completely in line with the results of this study.

This study has examined the relationship between different sub-tests in the specialized English section of the INUEE and their functions for both male and female test-takers. In fact, the study contributes to the literature on correlational studies since there have been no studies concerning the effect of gender on correlation coefficient among different subtests of the specialized English section of the INUEE. The study is significant in the sense that it has considered the effect of gender across the different subject areas and therefore has led to a set of interesting ideas.

Furthermore, as there have been very few studies checking for the reliability and validity of the specialized English section of the INUEE, especially with regard to test bias and correlation among different sub-tests, attempts can be made to include subject areas which are less permeable to bias.

\section{APPENDIX I ENGLISH TEST 1383}

\section{Part A: Grammar}

Directions: Questions 101-110 are incomplete sentences. Beneath each sentence you will see four words or phrases, marked (1), (2), (3), and (4). Choose the one word or phrase that best completes the sentences. Then mark the correct choice on your answer sheet.

101. He has been feeling badly since he ....... his job.
1) lost
2) loses
3) had lost
4) will lost

102. she doesn't know ........ causes her not do well on tests.
1) how
2) whom
3) what
4) why

103. The new pens require ....... than ordinary pens do.
1) the thicker ink
2) a thicker ink
3) the ink is thicker
4) an ink and thicker

104. It is good form to use the name of the person .........
1) who are greeting
2) whom you are greeting 3) which you are greeting
4) that you are greeting him

105. Students who fail ......... another chance to take the exam next June.
1) giving
2) will give
3) to give
4) will be give 
106. At last month's meeting the president asked the farmers if they ........ more trees immediately.
1) planted
2) would plant 3) will plant
4) have planted

107. Pineapples are not commercially produced in north America,

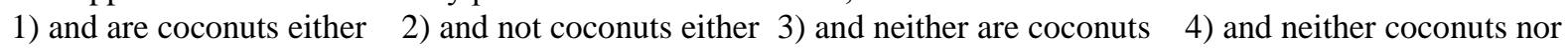

108. There was ........ evidence against John, so he was not accused of murder.
1) little
2) a little
3) few
4) a few

109. I don't mind ........ a cat in the house only if it is clean and it doesn't smell.
1) having
2) have
3) to have
4) that I have

110. I'm not responsible ........ what my brother does.
1) of
2) for
3) about
4) with

111. New chemicals are not always tested to determine if
1) it
2) those
3) they
4) that

112. Because it was so closely related to communication, ........ art form to develop.

1) the earliest draw 2) early drawing probably 3) to draw early was probably4) drawing was probably the earliest

\section{Part B: Vocabulary}

Directions: Questions 111-130 are incomplete sentences. Beneath each sentence you will see four words or phrases, marked (1), (2), (3), and (4). Choose the one word or phrase that best completes the sentences. Then mark the correct choice on your answer sheet.

113. He ....... the children by himself; his wife died years ago.
1) existed
2) raised
3) accepted
4) behaved

114. The meeting was supposed to be for today but was delayed at the
1) existed
2) advice
3) struggle
4) choice

115. I think it is ....... to keep animals in zoos.
1) serious
2) cruel
3) financial
4) emotional

116. Don't worry. There is ....... food for everybody.
1) fashionable
2) separate
3) available
4) sufficient

117. He has maybe one hundred books in his library covering every ........ of Iranian history.
1) aspect
2) memory
3) instance
4) resource

118. I applied for a ....... to study psychology at Oxford.
1) skill
2) reward
3) scholarship
4) competition

119. His smile was ....... of his approval of our plan.
1) productive
2) corrective
3) decisive
4) suggestive

120. You ....... her by saying that she looked ugly in that new dress.
1) offended
2) wondered
3) avoided
4) confined

121. Two of missing people have been found dead, but the third one has not yet been
1) set up
2) stuck in
3) accounted for
4) brought about

122. Nothing can ........ your being late for your sister's wedding.
1) interfere
2) justify
3) impose
4) affect

123. They talked about the ........ of the money supply, so that people could not spend so much.
1) procedure
2) restriction
3) capacity
4) pressure

124. The injured man was carried into the clinic on a .........
1) platform
2) device
3) shelter
4) stretcher

125. Nuclear energy seems to be a good ........ for fossil fuels.
1) replacement
2) calculation
3) equipment
4) application

126. Her ........ way of dressing makes her stand out wherever she goes.
1) various
2) inevitable
3) distinctive
4) severe

127. Mr. president will ........ the conference before the participants officially begin to work.
1) address
2) preach
3 ) announce
4) approach

128. The blame for the accident lies ....... with carelessness on the part of both drivers.
1) solely
2) mentally
3) closely
4) properly

129. The United Nations is supplying as much emergency aid to ........ as it can.
1) enemies
2) spectators
3) customers
4) refugees

130. She managed to ........ all her difficulties by working hard.
1) disperse
2) maintain
3) overcome
4) suffer

131. The ....... of men to women in the population has changed so that there are now fewer men and more women.
1) limitation
2) condition
3) registration
4) proportion

132. If you see a new word, you have to ....... the meaning of it in a dictionary.
1) make up
2) look up
3) turn up
4) call out

Part C: Word Order 
Directions: choose the sentence with the best order for each of the following series. Then mark the correct choice on your answer sheet.

133. 1) The red one looks on you does better than the striped one.

2) The red one looks better than the striped one does on you.

3) The red one looks better than on you the striped one does.

4) The red one looks better on you than the striped one does.

134. 1) Swimming is a sport I would recommend to any healthy person.

2) Swimming is to any healthy person a sport I would recommend.

3) Swimming is a sport to any healthy person I would recommend.

4) Swimming I would recommend is to any healthy person a sport.

135. 1) Anyone who uses without the owner's permission the trademark will be prosecuted.

2) Anyone who uses the trademark without the owner's permission will be prosecuted.

3) Anyone will be prosecuted who without the owner's permission uses the trademark.

4) Any will be prosecuted who uses the trademark without the owner's permission.

136. 1) Traveling at sixty miles an hour, the bus just missed the lamp-post and ran into the shop window.

2) The bus just missed the lamp-post traveling at sixty miles an hour and ran into the shop window.

3 ) The bus just missed the lamp-post and ran into the shop windows traveling at sixty miles an hour.

4) Traveling at sixty miles an hour, the lamp-post just missed and the bus ran into the shop window.

Part D: Language Functions

Directions: Read the following conversations between two people and answer the questions about the conversations by choosing one of the choices (1), (2), (3), or (4). Then mark the correct choice on your answer sheet.

Man: Want to go out and get something to eat?

Woman: I can't have a chemistry midterm on Monday and a German exam on Tuesday.

Man: I have a geology exam Monday myself, but I think I'm ready for it.

Woman: What kind of exam is it going multiple choice or essay?

Man: Neither. The professor is going to give us a mineral sample and we have to identify it.

Woman: How do you that? I mean. A rock's a rock. Isn't it?

Man: Actually, there are a lot of tests you can perform on minerals to help you figure out what they are. Probably the first tests I'll do are scratch tests. When you do a scratch test, you rub the sample on a known mineral to see if the unknown mineral scratches the known mineral or vice versa. That tells you the relative hardness of the sample.

Woman: What other tests will you do?

Man: I'll probably do a streak test next. In that test, you rub an unknown mineral against a piece of unglazed porcelain to see what color the streak is.

Woman: Why can't you just look at the mineral to see what color it is?

Man: Well, you can, but sometimes a mineral has a lot of impurities, and they can change its color but a streak test shows the minerals true color. Then there's always the specific gravity test, the blowpipe test, ... oh, and the ultraviolet test, and ....

Woman: And after you've done all these tests, you can positively identify any mineral?

Man: Well, usually ... but not always. I just hope I can on Monday!

137. What does the man ask the woman to do?
1) stay at home
2) go to a restaurant
3) go on a field trip
4) study for a language exam

138. What type of exam is the man taking on Monday?
1) an essay exam
2) a geology exam 3) a chemistry exam
4) a multiple-choice exam

139. What does a streak test show about a mineral?
1) its true color
2) its relative purity
3) its relative hardness
4) its chemical composition

140. What does the man imply about the test used to identify mineral?
1) they are never effective
2) they are simple to perform
3) they are not always conclusive
4) they are usually undependable

\section{Part E: Cloze Test}

Directions: Read the following passage and decide which choice (1), (2), (3), or (4) best fits each space. Then mark the correct choice on your answer sheet.

For the first century or so of the industrial revolution, increased productivity led to decreases in working hour employees who had been putting in 12-hour days, six days (41) ........ week, found their time on the (42) ........ shrinking to 10 hours daily, then (43) ........ to eight hours, five days a (44) ........ only a generation ago social planners (45) ........ about what people would do with (46) ........ this new-found free time. Although the (47) ........ per hour of work has more (48) ........ doubled since 1945, leisure seems reserved (49) ........ for the unemployed and underemployed. Those (50) ........ work fulltime spend as much time (51) ........ the job as they did at (52) ....... end of world war II. In (53) ........, working hours have increased noticeably since 1970- (54) ........ because real wages have stagnated since (55) ........ year. Book stores now abound with manuals describing how to manage time and cope with stress. 


$\begin{array}{llll}\text { 141. 1) a } & \text { 2) in } & \text { 3) the } & \text { 4) of } \\ \text { 142. 1) task } & \text { 2) work } & \text { 3) job } & \text { 4) profession } \\ \text { 143. 1) next } & \text { 2) absolutely } & \text { 3) thus } & \text { 4) finally } \\ \text { 144. 1) month } & \text { 2) year } & \text { 3) week } & \text { 4) day } \\ \text { 145. 1) proposed } & \text { 2) guessed } & \text { 3) worried } & \text { 4) informed } \\ \text { 146. 1) all } & \text { 2) complete } & \text { 3) entire } & \text { 4) whole } \\ \text { 147. 1) reason } & \text { 2) attempt } & \text { 3) shortage } & \text { 4) out put } \\ \text { 148. 1) of } & \text { 2) so } & \text { 3) as } & \text { 4) than } \\ \text { 149.1) terribly } & \text { 2) sharply } & \text { 3) largely } & \text { 4) lastly } \\ \text { 150. 1) who } & \text { 2) which } & \text { 3) whose } & \text { 4) they } \\ \text { 151. 1) for } & \text { 2) in } & \text { 3) on } & \text { 4) with } \\ \text { 152. 1) an } & \text { 2) the } & \text { 3) one } & \text { 4) first } \\ \text { 153. 1) fact } & \text { 2) action } & \text { 3) actively } & \text { 4) respect } \\ \text { 154. 1) properly } & \text { 2) except } & \text { 3) lately } & \text { 4) perhaps } \\ \text { 155. 1) a } & \text { 2) the } & \text { 3) that } & \text { 4) per }\end{array}$

\section{Part F: Reading Comprehension}

Directions: In this part of the test, you will read three passages. Each passage is followed by a number of questions. Answer the questions by choosing the best choice (1), (2), (3), or (4). Then mark the correct choice on your answer sheet.

\section{Questions 156-160}

Scientific research on tooth decay has recently produced some surprising findings. One shows that cheddar cheese may actually prevent the tooth-decay process. It seems to have decay-slowing effect on human teeth if it is eaten immediately after sugar. Why cheese should have such an effect is unknown. It is speculated that the food might interfere with the acid that decay teeth or with bacteria that produce the acid. If so, it would be the first common food found to have this useful property. The other surprising research finding was that heavily sweetened cereals proved about equally effective in causing decay whether they contained eight percent sugar or almost eight times that much.

156. The number of the findings referred to in this passage are .........
1) one
2) two
3) three
4) eight

157. Cheddar cheese seems to .........
1) make sugar state sweeter
2) help in the digestion of food
3 ) interfere with the function of teeth
4) decrease the rate at which teeth decay

158. The word "they" in line 7 refers to .........
1) people
2) teeth
3) cereal
4) types of sugar

159. It can be inferred from the passage that the research on the relationship between cheese and tooth decay 1) will be continued 2) has not been accepted 3) will be slowed considerably 4) has been found to be perfect

160. Researchers discovered that sweetened cereals were .........
1) all equally harmful to teeth
2) more expensive than cheese
3) all surprisingly heavy in sugar
4) important for their food value

\section{Question 161-165}

Few can predict a winner in the popular Tour de France, the annual twenty-four-day bike race over twenty-five hundred miles of French countryside. Anything can happen, and usually does, in this grueling cycle race which has been called the world's roughest road race. Accidents and exhaustion may force more than half the contestants to drop out before reaching the finish line.

A cyclist can stay in pack, finish respectably, and still suffer rough physical punishment, but the real dangers of the race become apparent when he decides to win. Cycling down a windswept mountain road, a racer may hit sixty miles an hour- with no hope of stopping; if he loses control then, he's out of the race in a split second, slamming over a cliff or into a rocky ditch. But the reward for the skillful and lucky winner is substantial - it's possible for him to earn as much as a hundred thousand dollars a year.

Hundreds of spectators follow the Tour de France in cars. And cheering crowds line the streets of every small town and village along the route. The Tour de France is a midsummer madness for which the United States has no counterpart, either in danger or in national appeal.

161. It is a fact that the Tour de France is .........
1) an auto endurance race
2) an annual cycle race
3) the world's most popular race
4) the world's roughest road race

162. More than half the racers may drop out because of .........
1) mechanical trouble
2) disqualifying cycle race
3) accidents and exhaustion
4) not wanting to try to win

163. Every racer can expect to receive .........
1) a fast bicycle
2) a physical punishment
3) a serious injury
4) a substantial award

164. The real dangers of the race become apparent as soon as
1) one accident occurs
2) the racers become tried
3) a racer decides to win
4) the pack nears the finish line 
165. The selection states that to win, it is most essential that a cyclist .........
1) be lucky and skillful
2) stay in the pack as long as possible
3) have previous experience on the course
4) have greater endurance than all the others

\section{Questions 166-170}

Edgar Allan Poe is today considered as one of the great authors of horror stories, but he received very little recognition and almost no money for his stories while he lived. Twenty-five of his greatest stories were published in a collection called Tales of the grotesque and Arabesque, which appeared in 1840, but at the time little notice was taken of it. Three years later, another story, "The Gold Bug," was published, selling 300,000 copies, and by 1845 he had written twelve more stories, which he published in Tales. His best-known stories include "The Pit and the Pendulum" and "The Tell-Tale Heart," but it was a poem, "The Raven," that brought him his greatest recognition as a writer.

The centerpiece of a collection of thirty poems published in a volume titled The Raven and Other Poems, it became quite popular. The topic of the poem is grief over the loss of an ideal love. The dramatic, almost theatrical tone, the intensity of the repetition, and the hypnotic rhythm reflect the narrator's despondent and desperate state of mind. When read aloud, it produces a powerful effect.

166. The author's main purpose in this passage is
1) to give examples of horror stories
2) to compare Poe's stories with his poems
3) to mention the work of Edgar Allan Poe
4) to indicate that The Raven be read aloud

167. According to the passage, the story that sold 300,000 copies was .........
1) The Raven
2) The Gold Bug
3) The Tell-Tale Heart
4) The Pit and the Pendulum

168. The word "it" in line 7 refers to ........
1) Tales
2) The Raven
3) The Tell-Tale Heart
4) The Pit and the Pendulum

169. All the following are mentioned about the Raven EXCEPT
1) dramatic tone
2) intense repetition
3) hypnotic rhythm
4) cheerful mood

170. It can be concluded from the passage that Edgar Allan Poe
1) died young
2) was poor all his life
3) suffered a mental problem
4) was married at a young age

\section{APPENDIX II CORRELATION BETWEEN DIFFERENT SUB-TESTS OF THE SPECIALIZED ENGLISH SECTION FOR MALE CANDIDATES}

\begin{tabular}{|ll|r|r|}
\multicolumn{3}{|c|}{ Correlations } \\
\hline & Grammar & $\begin{array}{c}\text { Language } \\
\text { structure }\end{array}$ \\
\hline Grammar & Pearson Correlation & 1 & $.290^{\star \star}$ \\
& Sig. (2-tailed) & & .000 \\
& $\mathrm{~N}$ & 329 & 329 \\
\hline Languagestructure & Pearson Correlation & $.290^{\star \star}$ & 1 \\
& Sig. (2-tailed) & .000 & \\
& $\mathrm{~N}$ & 329 & 329 \\
\hline
\end{tabular}

${ }^{* *}$. Correlation is significant at the 0.01 level (2-tailed).

\begin{tabular}{|c|c|c|c|}
\hline \multicolumn{4}{|c|}{ Correlations } \\
\hline & & Grammar & $\begin{array}{c}\text { Languagef } \\
\text { unctions }\end{array}$ \\
\hline \multirow[t]{3}{*}{ Grammar } & Pearson Correlation & 1 & $.286^{\star \star}$ \\
\hline & Sig. (2-tailed) & & .000 \\
\hline & $\mathrm{N}$ & 329 & 329 \\
\hline \multirow[t]{3}{*}{ Languagefunctions } & Pearson Correlation & $.286^{\star \star}$ & 1 \\
\hline & Sig. (2-tailed) & .000 & \\
\hline & $\mathrm{N}$ & 329 & 329 \\
\hline
\end{tabular}

**. Correlation is significant at the 0.01 level (2-tailed).

\begin{tabular}{|c|c|c|c|}
\hline \multicolumn{4}{|c|}{ Correlations } \\
\hline & & Grammar & Clozetest \\
\hline \multirow[t]{3}{*}{ Grammar } & Pearson Correlation & 1 & $.338^{\star \star}$ \\
\hline & Sig. (2-tailed) & & .000 \\
\hline & $\mathrm{N}$ & 329 & 329 \\
\hline \multirow[t]{3}{*}{ Clozetest } & Pearson Correlation & $.338^{\star \star}$ & 1 \\
\hline & Sig. (2-tailed) & .000 & \\
\hline & $\mathrm{N}$ & 329 & 329 \\
\hline
\end{tabular}


Correlations

\begin{tabular}{|ll|r|r|}
\hline & Vocabulary & $\begin{array}{l}\text { Language } \\
\text { structure }\end{array}$ \\
\hline Vocabulary & Pearson Correlation & 1 & $.267^{\star *}$ \\
& Sig. (2-tailed) & & .000 \\
& $\mathrm{~N}$ & 329 & 329 \\
\hline Languagestructure & Pearson Correlation & $.267^{\star \star}$ & 1 \\
& Sig. (2-tailed) & .000 & \\
& $\mathrm{~N}$ & 329 & 329 \\
\hline
\end{tabular}

${ }^{\star \star}$. Correlation is significant at the 0.01 level (2-tailed)

\begin{tabular}{|ll|r|r|}
\hline \multicolumn{1}{|c|}{ Correlations } \\
\hline & Vocabulary & $\begin{array}{c}\text { Languagef } \\
\text { unctions }\end{array}$ \\
\hline Vocabulary & Pearson Correlation & 1 & $.315^{\star \star}$ \\
& Sig. (2-tailed) & .000 \\
& $\mathrm{~N}$ & 329 & 329 \\
\hline Languagefunctions & Pearson Correlation & $.315^{\star \star}$ & 1 \\
& Sig. (2-tailed) & .000 & \\
& $\mathrm{~N}$ & 329 & 329 \\
\hline
\end{tabular}

${ }^{\star \star}$. Correlation is significant at the 0.01 level (2-tailed).

Correlations

\begin{tabular}{|ll|r|r|}
\hline & & Vocabulary & Clozetest \\
\hline Vocabulary & Pearson Correlation & 1 & $.351^{\star \star}$ \\
& Sig. (2-tailed) & & .000 \\
& $\mathrm{~N}$ & 329 & 329 \\
\hline Clozetest & Pearson Correlation & $.351^{\star \star}$ & 1 \\
& Sig. (2-tailed) & .000 & \\
& $\mathrm{~N}$ & 329 & 329 \\
\hline
\end{tabular}

${ }^{\star *}$. Correlation is significant at the 0.01 level (2-tailed).

\begin{tabular}{|ll|r|r|}
\hline \multicolumn{1}{|c|}{ Correlations } \\
\hline Languagestructure & $\begin{array}{c}\text { Language } \\
\text { structure }\end{array}$ & $\begin{array}{c}\text { Languagef } \\
\text { unctions }\end{array}$ \\
& Pearson Correlation & 1 & $.270^{* *}$ \\
& Sig. (2-tailed) & & .000 \\
& $\mathrm{~N}$ & 329 & 329 \\
\hline Languagefunctions & Pearson Correlation & $.270^{* *}$ & 1 \\
& Sig. (2-tailed) & .000 & \\
& $\mathrm{~N}$ & 329 & 329 \\
\hline
\end{tabular}

${ }^{\star *}$. Correlation is significant at the 0.01 level (2-tailed)

\begin{tabular}{|ll|r|r|}
\hline \multicolumn{3}{|c|}{ Correlations } \\
\hline & & $\begin{array}{l}\text { Language } \\
\text { structure }\end{array}$ & Clozetest \\
\hline Languagestructure & Pearson Correlation & 1 & $.247^{\star \star}$ \\
& Sig. (2-tailed) & & .000 \\
& $\mathrm{~N}$ & 329 & 329 \\
\hline Clozetest & Pearson Correlation & $.247^{\star *}$ & 1 \\
& Sig. (2-tailed) & .000 & \\
& $\mathrm{~N}$ & 329 & 329 \\
\hline
\end{tabular}

${ }^{* *}$. Correlation is significant at the 0.01 level (2-tailed).

\begin{tabular}{|ll|r|r|}
\hline \multicolumn{1}{|c|}{ Correlations } \\
\hline & $\begin{array}{l}\text { Language } \\
\text { structure }\end{array}$ & $\begin{array}{l}\text { Readingcom } \\
\text { prehension }\end{array}$ \\
\hline Languagestructure & Pearson Correlation & 1 & $.263^{\star *}$ \\
& Sig. (2-tailed) & & .000 \\
& $\mathrm{~N}$ & 329 & 329 \\
\hline Readingcomprehension & Pearson Correlation & $.263^{\star \star}$ & 1 \\
& Sig. (2-tailed) & .000 & 329 \\
& $\mathrm{~N}$ & 329 & 329 \\
\hline
\end{tabular}

${ }^{* *}$. Correlation is significant at the 0.01 level (2-tailed). 
Correlations

\begin{tabular}{|ll|c|r|}
\hline & $\begin{array}{l}\text { Languagef } \\
\text { unctions }\end{array}$ & Clozetest \\
\hline Languagefunctions & Pearson Correlation & 1 & $.368^{\star *}$ \\
& Sig. (2-tailed) & & .000 \\
& $\mathrm{~N}$ & 329 & 329 \\
\hline Clozetest & Pearson Correlation & $.368^{\star *}$ & 1 \\
& Sig. (2-tailed) & .000 & \\
& $\mathrm{~N}$ & 329 & 329 \\
\hline
\end{tabular}

${ }^{* *}$. Correlation is significant at the 0.01 level (2-tailed)

\begin{tabular}{|ll|r|r|}
\hline \multicolumn{1}{|c|}{ Correlations } \\
\hline & Pearson Correlation & 1 & $.414^{* *}$ \\
\hline Clozetest & & .000 \\
& Sig. (2-tailed) & 329 & 329 \\
\hline & $\mathrm{N}$ & $.414^{\star *}$ & 1 \\
\hline Readingcomprehension & Pearson Correlation & .000 & \\
& Sig. (2-tailed) & 329 & 329 \\
& $\mathrm{~N}$ &
\end{tabular}

${ }^{* *}$. Correlation is significant at the 0.01 level (2-tailed)

\section{REFERENCES}

[1] Alderson, J. C. (1984). Reading in a foreign language: a reading problem or a Language problem? In J. C. Alderson \& A. H. Urquhart (Eds.), Reading in a foreign language (pp.1-27). New York: Longman Incorporation.

[2] Alderson, J. C. (1993). The relationship between grammar and reading in English for academic purposes test battery. In D. Douglas, \& C. Chapelle (Eds.), A new decade of language testing research (pp.447-467). Alexandria, VA: TESOL.

[3] Anderson, R. C., \& Freebody, P. (1981). Vocabulary knowledge. In J. T. Guthrie (Ed.), Comprehension and teaching: research review (pp. 77-117). New York: International Reading Association.

[4] Berman, R. A. (1984). Syntactic components of the foreign language reading process. In J. C. Alderson, \& A. H. Urquhart (Eds.), Reading in a foreign language (pp.49-74). New York: Longman.

[5] Eskey, D. E. (1973). A model for teaching and advanced reading to students of English as a foreign language. Language Learning, 23, 169-189.

[6] Gestern, R., \& Baker, S. (1999). Reading comprehension for students with learning disabilities. New York: National Center for Learning Disabilities.

[7] Gestern, R., \& Geva, E. (2003). Teaching reading to early language learners. Educational Leadership, 60(7), 89-94.

[8] Henning, G. (1987). A guide to language testing: development, evaluation, research. University of Bristol: Heinle \& Heinle Publishers.

[9] Hunston, S. (1997). Grammar and vocabulary: showing the connection. ELT Journal, 51(3), 208-216.

[10] Irvin, J. L. (2001). Assessing struggling readers in building vocabulary and background knowledge. Voices from the Middle, 8(11), 37-43.

[11] Koda, K. (1989). The effect of transferred vocabulary knowledge on the development of second language reading proficiency. Foreign Language Annals, 22, 529-540.

[12] Laufer, B., \& Hulstijn, J. (2001). Incidental vocabulary acquisition in a second language: the construct of task-induced involvement. Applied Linguistics, 22 (1), 1-26.

[13] Lin, J. (2002). Discovering EFL learners' perception of prior knowledge and its roles in reading comprehension. Journal of Research in Reading, 25(2), 172-190.

[14] Panel, N. R. (2000). Teaching children to read: an evidence-based assessment of scientific research literature on reading and its implications for reading instruction. Washington D. C.: National Institute of Child Health and Human Development.

[15] Pearson, I. (1988). Test as levels for change. ESP in the Classroom: Practice and Evaluation. London.

[16] Rivers, W. M. (1983). Teaching foreign language skills. Chicago: Chicago University Press.

[17] Safikhani, A. (2009). Washback effect of University Entrance Exam on the EFL teaching methodology: A case in Iranian high schools and pre-university centers. Unpublished M.A. Thesis, Najaf Abad University.

[18] Savington, S. (1997). Communicative competence: theory and classroom practice. New York: McGrow Hill.

[19] Spratt, M. (2005). Washback and the classroom: the implication for teaching and learning of studies of washback from exam. Language Teaching Research, 20, 5-29.

[20] Urquhart, A. H., \& Weir, C. J. (1998). Reading in a second language: process, product, and practice. New York: Longman.

[21] Yamini, M. \& Rahimi, M. (2007). A guide to statistics and SPSS for research in TEFL, linguistics and related disciplines. Shiraz University: Koshamehr. 


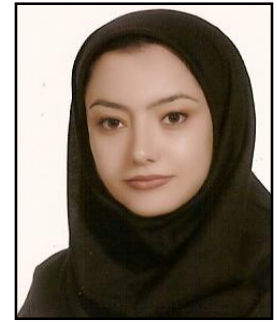

Maryam Javadizad was born in Isfahan, Iran in 1982. She is now a M.A. student in TEFL in Department of English, Najafabad Branch, Islamic Azad University, Najafabad, Iran.

Her research interests include Applied Linguistics, Testing, and Sociolinguistics.

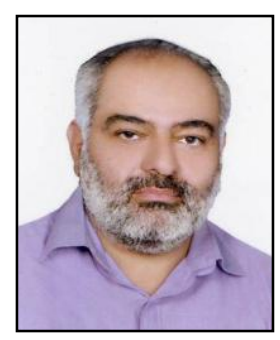

Hossein Barati has a $\mathrm{PhD}$ in "Language Testing" from University of Bristol and has been involved in research in language testing, programme evaluation, reading strategies, and classroom discourse.

He works in the English department, University of Isfahan, where he is Assistant Professor of Applied Linguistics. He has published in areas of language testing and assessment, and language programme evaluation. He is currently working on "New plans for Teaching English to Iranian adult non-majors", "Teaching English to Iranian young learners", and "The consequential validity of high stakes tests in the Iranian context".

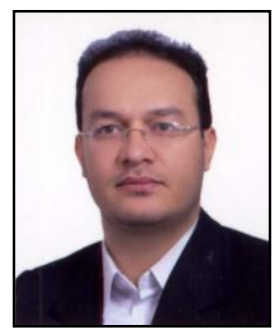

Akbar Hesabi has $\mathrm{PhD}$ in applied linguistics and works as lecturer and one of Teaching Assistance at English Department, University of Isfahan, Iran.

His areas of interest include Linguistics, Neurolinguistics, Computational Linguistics and Machine Translation. He has published several articles in these areas. 